DOI: https://doi.org/10.18371/fp.4(44).2021.081923

УДК 334.72

\title{
МОДЕЛІ ДЕРЖАВНО-ПРИВАТНОГО ПАРТНЕРСТВА У 3ОВНІШНЬОЕКОНОМІЧНІЙ ДІЯЛЬНОСТІ: ФОРМИ, МЕХАНІЗМИ, ДЕКОМПОЗИЦІЯ
}

\section{ПИРОГ Ольга Володимирівна}

доктор економічних наук, професор,

завідувач кафедри менеджменту і міжнародного підприємництва, НУ «Львівська політехніка»

ORCID ID: https://orcid.org/0000-0002-6714-3079

\section{ТОМИЧ Мар'яна Ігорівна}

аспірант кафедри менеджменту і міжнародного підприємництва, НУ «Львівська політехніка»

ORCID ID: https://orcid.org/0000-0001-5340-1877

\section{ВОРОНОВСЬКА Марта Миколаївна}

\section{к.е.н., дочент}

дочент кафедри менеджменту і міжнародного підприємництва, НУ «Львівська політехніка»

ORCID ID: https://orcid.org/0000-0002-3539-0171

\begin{abstract}
Анотація. У статті досліджено моделі державно-приватного партнерства (ДПП) та вказано на доиільність їх використання при реалізації проєктів ДПП у зовнішньоекономічній діяльності. Це дозволило визначити форми та механізми ДПП у зовнішньоекономічній сфері. 3 метою підвищення рівня результативності ДПП, у статті застосовано структурний та об'єктно-орієнтовний підходи до моделювання та сформовано відповідний порядок моделювання ДПП у зовнішньоекономічній діяльності.

Ключові слова: державно-приватне партнерство, зовнішньоекономічна діяльність, моделі, форми, механізми, декомпозицุiя.
\end{abstract}

Постановка проблеми. Як відомо, моделі - це відображення у формі конструкцій, описі, математичному
Аннотация. $B$ cmатье исследованы модели государственно-частного партнерства (ГЧП) и указано на целесообразность их использования при реализаџии проектов ГЧП во внешнеэкономической деятельности. Это позволило определить формы и механизмы ГЧП во внешнеэкономической сфере. С иелью повышения уровня результативности ГЧП, в статье применен структурный $u$ объектно-ориентировочный подходы к моделированию и сформирован соответствующий порядок моделирования ГЧП во внешнеэкономической деятельности.

Ключевые слова: государственночастное партнерство, внешнеэкономическая деятельность, модели, формы, механизмы, декомпозиция.

виразі характерних властивостей об'єкту. Вони відтворюють принципи функціонування об’єкту, а також во- 
лодіють його основними характеристиками. У міжнародних економічних відносинах та економічній науці загалом, моделі використовуються для вивчення економічних законів і взаємодій, управлінських ситуацій і процесів світової економіки тощо. Їх застосовують $з$ метою забезпечення розвитку об'єктів у таких умовах, коли їх дослідження є складним чи взагалі не можливим.

Моделі ДПП, як економічної взаємодії, є умовним (описовим) аналогом проєктів державного і приватного секторів та характеризують форми співробітництва між учасниками проєктів (представниками секторів), типи укладених контрактів, методи їх укладання тощо. Їх вивчення спрямоване на розвиток ДПП, у зовнішньоекономічній діяльності зокрема, підвищення результативності проєктів ДПП за умови залучення суб'єктів господарської діяльності України та іноземних суб'єктів господарської діяльності (також суб'єктів господарської діяльності України із іноземними державами). Це забезпечує можливість ефективно вирішувати актуальні питання, пов'язані із розвитком економічних систем та розв'язувати вагомі економічні та соціальні проблеми тощо.

Таким чином, 3 метою залучення необхідних інвестиційних ресурсів, підвищення інноваційної активності в економіці, розвитку економічної та соціальної інфраструктури, вирішення економічних та соціальних проблем тощо, ретельного вивчення потребують моделі ДПП у зовнішньоекономічній діяльності.

Аналіз останніх досліджень та публікацій Моделі ДПП досліджували та класифікували відомі вітчизняні та іноземні вчені-економісти, серед яких
О.В. Длугопольський, А. Ю. Жуковська, І. А. Брайловський, С. Н. Кузьміна, I. А. Бабкін, В. В. Круглов, С. Підгаєць, М. А. Мащенко, М. Деватріпонт, П. Легро, Л.Шарінгер, О.М. Вінник, П.І.Шилепницький, Р.Хусаінов та інші [1-14].

За матеріалами Світового банку, виділено чотири базові моделі ДПП:

1. Контракти на управління та лізинг;

2. Концесії (реалізується у формах «ROT» (відновлення, експлуатація, передавання), «RLT» (відновлення, оренда (лізинг), передавання), «BROT» (будівництво, відновлення, експлуатація, передавання));

3. Проєкти «зеленого поля» (проєкти «з чистого аркуша», GreenfieldProjects), які передбачають те, що приватний партнер самостійно або спільно 3 державою будує і експлуатує новостворений об'єкт у межах контрактного терміну. Вони виконуються за допомогою механізмів «BLT» (будівництво, оренда, передавання), «ВОТ» (будівництво, експлуатація, передавання), «ВОО» (будівництво, володіння, управління);

3. Продаж активів. Модель містить схеми купівлі приватним сектором частини об'єкту в державного сектору через розміщення вільних коштів у купівлю акції або через програми приватизації $[1,2]$. При цьому Підгаєць С. зазначає, що вибір моделей здійснює уряд держави залежно від сфер і характеру послуг, які є предметом ДПП.

Як зазначає Мащенко М. А., в основі класифікації моделей ДПП світовим банком лежить наступний критерій: питома вага участі приватної компанії у розподілі експлуатаційних ризиків та експлуатаційних витрат [3]. Також автором наведено моделі ДПП, які 
поширені США: партнерство для успішної реалізації пріоритетних інфраструктурних проектів (зокрема, передбачають процедуру пакетного тендеру); партнерство для реалізації великих і складних програм із залученням управлінської експертизи приватного партнера; партнерство 3 метою залучення нових технологій, розроблених у приватному секторі; партнерство з метою залучення різноманітних фінансових ресурсів, доступних для бізнесу; партнерство із розвитку створених інфраструктурних об'єктів приватним партнером, які супроводжуються передачею власності на споруджений об'єкт і, відповідно, управління ним та іншим капіталом. Також автор наводить моделі ДПП Свропейського союзу: сервісний контракт, при якому приватна компанія здійснює експлуатацію державних активів; контракт на управління і експлуатацію; оренда; будівництво «під ключ»; «DBFO» (проектування, будівництво, фінансування і експлуатація). На нашу думку, при визначенні моделей ДПП, які характерні для США автор виходив із мети та завдань проєктів взаємодії державного і приватного секторів. Досягнення цих цілей можливе шляхом укладення різних договорів та реалізації відповідних механізмів, до яких зарахуємо укладення концесійних угод, трансфер технологій тощо. Як зазначено у [4] класифікація моделей ДПП США відрізняється також характером розподілу відповідальності між державним і приватним сектором, що включає також і питання розподілу ризиків. Тут автор згадує про наявність таких моделей ДПП як «DB» (проектування і будівництво), «DBO»/«DBM» (проектування, будів- ництво і експлуатація/утримання»), про них мова піде нижче.

Щодо моделей ДПП, які характерні для Європейського союзу, то автором зараховано до них «DBFO», що $\epsilon$ механізмом реалізації відповідних моделей ДПП. Цю думку можна простежити і у праці І. А. Брайловського «Передача активів - роздержавлення як одна із моделей державно-приватного партнерства», де детально вивчено основні типи контрактів у рамках категорії моделей ДПП (згідно методології європейського союзу): «ВОО», «DBFO», «PFI» (приватна фінансова ініціатива) тощо [5]. Аналогічний недолік характерний для моделей ДПП у зовнішньоекономічній діяльності, які виділені П.І. Шилепницьким[2, 6]. У дослідженнях автора наведено такі види моделей ДПП: контракти на послуги, операційні та управлінські контракти, лізингові контракти, «ВОТ» («ВООТ» (будівництво, володіння, управління, передавання), «ВLOT» (будівництво, оренда, експлуатація, передавання), «ВROT», «ВTO» (будівництво, передача, експлуатація)), «DBFO» («BOO» (будівництво, володіння, експлуатація), «BDO» (будівництво, розвиток, експлуатація), «DCMF» (проектування, будівництво, менеджмент, фінансування)). Зазначимо, що «BOT» та «DBFO» не можуть бути зараховані до моделей, адже вони містять лише конкретні механізми для їх реалізації, що засновані на укладенні та виконанні відповідних контрактів, в т.ч. зовнішньоекономічних, розподілі прав, обов'язків та відповідальності учасників проєктів ДПП.

Топологія моделей ДПП за класифікацією світового банку використана Брайловським I.А. при вивченні меха- 
нізмів ДПП. Зокрема, автором здійснено класифікацію моделей ДПП за п’ятьма основними категоріями в порядку збільшення участі у проєктах ДПП та взяття на себе ризиків приватним сектором: контракти постачання й управління; проекти під ключ; оренда; концесії; приватна власність на активи (роздержавлення) [7]. Як бачимо, залежно від обраних автором класифікаційних ознак, контракти на управління та лізинг (оренда) розглянуто як окремі моделі ДПП, у матеріалах світового банку вони розглянуті як єдина модель.

У країнах Азії практично були реалізовані наступні моделі ДПП у зовнішньоекономічній діяльності: договір на обслуговування (найм приватної фірми для надання послуг на державних об'єктах на короткий період часу (від 1 до 3 років)), договір на управління (залучення приватного сектора без продажу активів), договір оренди, договір концесії, спільне підприємство (спільне володіння i управління державним і приватним секторами одночасно) [8]. Як бачимо, за сутнісними ознаками вони схожі до моделей ДПП, що визначені світовим банком.

Длугопольський О. В., Жуковська А. Ю. зазначають те, що світовою практикою сформовано п'ять основних моделей ДПП та вказують на термін їх реалізаціі: модель оператора i модель кооперації (5-10 років), модель концесії (20-30 років), модель договору (3-5 років), модель лізингу (8-15 років) [9]. Ці базові моделі ДПП характеризуються специфічними формами відносин власності, джерелами фінансування та управління. Вони запропоновані Л. Шарінгером в 2004 р. [10].
Для цих моделей С. Н. Кузьміна та I. А. Бабкін рекомендують реалізацію відповідних форм договорів (договір на оперативне управління, формування спільних підприємств, концесій різних видів, укладання сервісних контрактів та контрактів на управління, оренда, лізинг, угода про розподіл продукції), розподіл прав та обов'язків у процесі фінансування та управління проектами ДПП [11].

В.В. Кругов моделі ДПП визначає як контракти (угоди) на управління, лізингові (орендні) угоди, концесійні моделі [12]. Автором здійснено їх класифікацію на:

- проєкти (угоди), що передбачають створення нових об'єктів на умовах концесії;

- угоди, що передбачають створення нових об'єктів.

Для перших наведено різновиди концесійних контрактів: «ВООТ», «BLOT», «ВОT», «ВОМТ» (будівництво, експлуатація, обслуговування, передавання), «DBOOT» (проектування, будівництво, володіння, експлуатація, передавання), «DBFO» (проектування, будівництво, фінансування, експлуатація), «ВВО» (придбання, будівництво, експлуатація), «BLT». Для других автором наведено моделі: «ROT», «RLT», «BROT». Також Кругов В.В. здійснив класифікацію наведених вище моделей ДПП залежно від розподілу ризиків та рівня залучення приватного сектора. 3 наведеного вище матеріалу можемо зробити висновок, що автор ототожнює поняття моделей ДПП, напрямів реалізації угод (механізмів ДПП) та типів контрактів. На нашу думку ці категорії слід відокремлювати один від одного, адже кожна із моделей передбачає різні ме- 
ханізми реалізації та супроводжується укладанням різного типу угод.

У праці О.М. Вінника до правових форм та моделей ДПП віднесено «О\&М» (експлуатація та технічне обслуговування), «ОММ» (експлуатація, технічне обслуговуванням та управління), «DB», «DBO», «DBM», «DBOM» (проектування, будівництво, експлуатація та технічне обслуговування), «DBFOM» (проектування, будівництво, фінансування, експлуатація та технічне обслуговування), «DBFOMT» (проектування, будівництво, фінансування, експлуатація, технічне обслуговування, передача), $\langle$ ВОT», «ВОO», «ВОТ», «ВВО» [13].

Брайловський I.A. рекомендує три моделі ДПП, які доцільно реалізувати в Україні:

Модель 1. Державний сектор допускає приватного інвестора в сферу своєї відповідальності, що будує i/або управляє об'єктом протягом певного строку. Рекомендовано наступні механізми реалізації цієї моделі: ВОТ, BOOT, BTO, BOO, BOMT, DBOOT, DBFO, BOLT, Brownfield, Servicecontract, лізинг і ін. Рекомендовано застосовувати у інфраструктурних проєктах.

Модель 2. Держава створює умови та формує всю необхідну інфраструктуру для реалізації проекту приватним інвестором. Таку модель слід застосовувати шляхом реалізації спільних проектів. Модель слід використовувати у сфері інновацій та високих технологій.

Модель 3. Пряма участь держави у проєкті приватної компанії, для чого слід застосувати Фонди прямих інвестицій $з$ участю держави. Модель рекомендована у сфері інновацій [14].
Р. Хусаінов у своїй праці «Моделі державно-приватного партнерства: закордонний досвід та перспективи для України» здійснив класифікацію моделей правових режимів ДПП за критерієм структури правового забезпечення державно-приватного партнерства (модель відсутності профільних комплексних нормативноправових актів у галузі ДПП, модель мінімального збалансованого правового регулювання окремих аспектів ДПП, модель, яка характеризується наявністю спеціального комплексного профільного нормативно-правового акту (актів) в сфері ДПП, модель, яка характеризується певною редундантністю) та за критерієм наявності та статусу спеціального органу управління у сфері державно-приватного партнерства (модель одного спеціального органу управління у сфері ДПП, модель відразу декількох спеціальних органів державного або державногромадського управління, модель відсутності спеціального профільного органу державного або державногромадського управління у сфері ДПП) [8].

На підставі аналізу досліджень та публікацій за проблемою сутності, різновидів моделей ДПП у зовнішньоекономічній діяльності відзначимо наступне. У наукових дослідженнях відсутні публікації, які присвячені сутності та класифікації моделей ДПП у зовнішньоекономічній сфері. У практиці реалізації проектів ДПП, які виконанні у низці країн (Великобританія, США, країни Азії), включаючи проекти ДПП у зовнішньоекономічній сфері, що ініційовані цими країнами, можуть бути застосовані різноманітні моделі.

Щодо самого поняття моделей ДПП та їх різновидів, серед дослідників 
спостерігається єдність думок відносно того, що не існує єдиної моделі ДПП, яка би могла бути реалізована у країні чи у зовнішньоекономічній сфері. Проте перелік діючих моделей ДПП істотно відрізняється, залежно від обраної класифікації. Також відзначимо ототожнення понять «Модель ДПП», «Форма ДПП», «Механізм ДПП» у окремих літературних джерелах. На нашу думку, ці поняття не є тотожними, слід вказати на відмінності між ними.

Мета статті. Відповідно до окресленої проблематики, у статті слід визначити моделі, форми та механізми ДПП у зовнішньоекономічній діяльності. Для підвищення результативності ДПП у зовнішньоекономічній діяльності слід забезпечити декомпозицію моделей ДПП, використовуючи структурний та об'єктно-орієнтовний підходи до моделювання.

Виклад основного матеріалу дослідження. Для досягнення мети статті, візьмемо за основу класифікацію моделей ДПП Світового банку, згідно якої до них зараховують: угоди на управління, лізинг (оренда), концесія, угоди про створення чи реконструкцію об'єктів, продаж активів.

Для визначення поняття форми ДПП використаємо результати досліджень С. Н. Кузьміної та I. А. Бабкіна та вважатимемо під ними форми укладання контрактів ДПП у зовнішньоекономічній сфері (договори на оперативне управління, договір концесії, договори оренди, лізингу, договори щодо розподілу продукції).

Щодо механізмів реалізації моделей ДПП, використаємо ідеї І. А. Брайловського, що визначили рекомендовані ним моделі ДПП для України. А саме, вважаємо за доцільним у межах моде- лей ДПП виділяти різноманітні механізми для їх реалізації: «ROT», «RLT», $\langle\mathrm{BROT} »,\langle\langle\mathrm{BLT}\rangle,\langle\mathrm{BOT}\rangle,\langle\mathrm{BOO} »$, $\langle\mathrm{BOOT} »,\langle\langle\mathrm{DBFO} », \quad\langle\mathrm{DB} »,\langle\langle\mathrm{DBO} »$, $\langle\mathrm{DBM} », \quad\langle\mathrm{PFI} », \quad\langle\mathrm{BLOT} », \quad\langle\mathrm{BOT} »$, $\langle$ BROT», «BTO», «DCMF» тощо. Результати досліджень узагальнені в табл. 1.

Різноманітність моделей ДПП у зовнішньоекономічній діяльності, а також наявність відмінних форм їх реалізації та механізмів (табл. 1) вимагає належної уваги питанням їх обрання, що потребує ретельного підходу, визначення переваг та недоліків в умовах невизначеності та існування системи обмежень. Дослідимо це докладHо.

Як зазначалось, вибір моделей ДПП у зовнішньоекономічній діяльності здійснює уряд держави залежно від сфер i характеру послуг, які $\epsilon$ його предметом. У Великобританії ця функція покладена на Partnerships UK. Цей орган є не лише консультантом, але і розробником проєктів ДПП, здійснює їх оцінку та супровід впродовж терміну їх реалізації, розділяє ризики і прибутки проєктів тощо [15].

При виборі моделей ДПП у зовнішньоекономічній діяльності слід забезпечувати їх оптимальність. Оптимальні моделі партнерства повинні сприяти отриманню таких вигод: швидша реалізація складних інфраструктурних проектів; підвищення рівня соціальноекономічної ефективності та розвитку регіонів; підвищення рівня надання публічних послуг та державного управління; зниження рівня витрат при реалізації інвестиційнихпроєктів; оптимізація структури фінансування за рахунок доступу до іноземних грошових ресурсів тощо [9]. 
Таблиця 1

Моделі ДПП у зовнішньоекономічній сфері та притаманні їм форми та механізми реалізації

\begin{tabular}{|c|c|c|c|}
\hline $\begin{array}{l}\text { № } \\
3 / \Pi\end{array}$ & $\begin{array}{c}\text { Моделі ДПП у } \\
\text { зовнішньоекономічній } \\
\text { сфері }\end{array}$ & $\begin{array}{l}\text { Форми ДПП у зовнішнь- } \\
\text { оекономічній сфері }\end{array}$ & $\begin{array}{c}\text { Механізми ДПП у зовнішньоеко- } \\
\text { номічній сфері }\end{array}$ \\
\hline 1 & Угоди на управління & $\begin{array}{c}\text { Договір на оперативне } \\
\text { управління, сервісні кон- } \\
\text { тракти тощо }\end{array}$ & $\begin{array}{l}\text { «ROT», «RLT», «O\&M», «OMM», } \\
\text { «PFI» }\end{array}$ \\
\hline 2 & Лізинг (оренда) & Угоди оренди (лізингу) & $\langle\mathrm{O} \& \mathrm{M} »,\langle\mathrm{OMM} »,\langle\mathrm{PFI}\rangle$ \\
\hline 3 & Концесія & $\begin{array}{l}\text { Договори концесії щодо } \\
\text { створення, рекон- } \\
\text { струкції, управління } \\
\text { об'єктом }\end{array}$ & 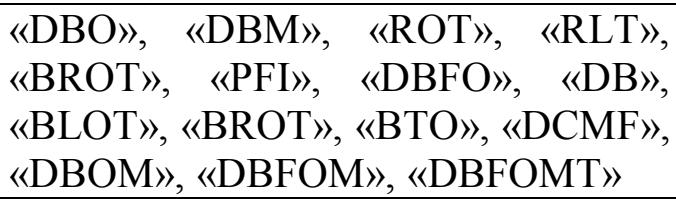 \\
\hline 4 & $\begin{array}{l}\text { Угоди про створення } \\
\text { чи } \\
\text { об’єктів }\end{array}$ & $\begin{array}{c}\text { Створення спільних } \\
\text { підприємств, договори } \\
\text { про розподіл продукції } \\
\text { тощо }\end{array}$ & 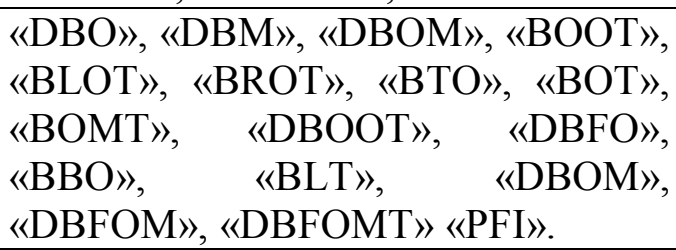 \\
\hline 5 & Продаж активів & $\begin{array}{c}\text { Первинне розміщення } \\
\text { акцій, приватизація }\end{array}$ & $\begin{array}{l}\text { «ROT», «RLT», «O\&M», «OMM», } \\
\text { «PFI» }\end{array}$ \\
\hline
\end{tabular}

Джерело: розроблено автором за [1-14]

3 метою підвищення результативності проєктів ДПП у зовнішньоекономічній діяльності, рекомендуємо декомпозицію їх складових, що забезпечить реалізацію процесно-структурованого підходу, що дозволить здійснити їх оптимізацію. Для цього визначимо ключові аспекти обрання моделі ДПП у зовнішньоекономічній діяльності.

В першу чергу, вибір моделей ДПП визначає розподіл прав приватної та державної власності. Від рівня залучення приватного сектору залежать ризики проєктів ДПП [12]. При виборі моделі ДПП слід ураховувати рівень фінансування, що віднесено до ключових елементів моделей ДПП [14].

Ступінь участі та рівень зацікавленості приватного сектору у державноприватному партнерстві визначають особливості, притаманні різним галузям суспільної інфраструктури (капі- таломісткість, ризиковість, технологічна складність) [9].

На думку I.А. Брайловського обрання моделі ДПП грунтується на таких ключових аспектах: перелік функцій щодо проектування, будівництва, управління, експлуатації тощо, які держава хоче передати на здійснення приватному сектору при ДПП у зовнішньоекономічній діяльності; масштаб проєкту; контроль якості реалізації проекту; розподіл ризиків між державним і приватним сектором, а також управління ними; способи покриття витрат приватного сектору (який механізм оплати буде застосовано) [7].

Також вибір моделей ДПП у зовнішньоекономічній діяльності обумовлюється розміром інвестицій, необхідним для реалізації проєктів, ризиками їх реалізації, зобов'язаннями та тривалістю проєктів[5].

На підставі узагальнення матеріалів останніх досліджень та публікацій за 
проблемою, та, враховуючи аналітичні матеріали щодо реалізації проектів ДПП у зовнішньоекономічній діяльності, виділимо такі ключові елементи моделей ДПП (I_мдпп):

1. Рівень розподілу прав приватної та державної власності $\left(\mathrm{P}_{\text {рпв }}\right)$;

2. Фінансування $\left(\Phi_{n}\right)$;

3. Функції (проектування, будівництво, управління, експлуатації тощо), які держава хоче передати на здійснення приватному сектору при ДПП у зовнішньоекономічній діяльності $\left(\Pi_{\phi \Pi}\right)$;

4. Масштаби та тривалість проєкту $\left(\mathrm{MT}_{\Pi}\right)$;

5. Рівень ризиків державного i приватного сектору ( $\left.\mathrm{P}_{\text {рдпп }}\right)$.

Таким чином, множину моделей ДПП у зовнішньоекономічній діяльності представимо як S. Вона формується під впливом обраних ключових аспектів, що математично можна виразити так:

$$
S=\left\{\bigcup_{\mathrm{i}=1}^{5} \mathrm{I}_{\mathrm{M} д \Pi \amalg}\right\}=\left\{\mathrm{P}_{\mathrm{pm}} ; \Phi_{\Pi} ; \Pi_{\phi \pi} ; \mathrm{M}_{\Pi} ; \mathrm{P}_{\mathrm{pдmI}}\right\}
$$

Кожний із ключових аспектів вибору моделі ДПП у зовнішньоекономічній діяльності може набувати різних станів, які слід ретельно розглянути.

Рівень розподілу прав приватної та державної власності $\left(\mathrm{P}_{\text {рпв }}\right)$ має кілька станів. Як відомо, проєкти ДПП можуть передбачати передачу об'єктів у власність приватного партнера $\left(\mathrm{B}_{\text {пп }}\right)$, або збереження прав володіння державного сектору $\left(\mathrm{B}_{\text {дп }}\right)$, спільну власність на об'єкти ДПП (державна на приватна власність) ( $\left.\mathrm{B}_{\text {пд }}\right)$, що може бути виражено так:

$$
\mathrm{P}_{\text {рпв }}=\left\{\bigcup_{i=1}^{3} \mathrm{P}_{\text {рпв }}\right\}=\left\{\mathrm{B}_{\Pi \Pi} ; \mathrm{B}_{\text {пд }} ; \mathrm{B}_{\text {дп }}\right\}
$$

Фінансування проєктів ДПП ( $\left.\Phi_{п}\right)$ може відбуватись 3 ініціативи та за рахунок державного партнера $\left(\Phi_{\text {пд }}\right)$, реалізовуватись у формі спільного фінансування (державно-приватного) $\left(\Phi_{\text {дп }}\right)$ чи приватного фінансування $\left(\Phi_{\text {กII }}\right)$ :

$$
\Phi_{\text {п }}=\left\{\bigcup_{i=1}^{3} \Phi_{\Pi}\right\}=\left\{\Phi_{\Pi} ; \Phi_{\text {дп }} ; \Phi_{\text {пд }}\right\}
$$

Функції, які держава хоче передати на здійснення приватному сектору при ДПП у зовнішньоекономічній діяльності $\left(\Pi_{\phi п}\right)$ визначають механізми ДПП, що будуть застосовані у проєктах. Їх перелік визначено в табл. 1, а тлумачення здійснено вище при розгляді моделей ДПП у зовнішньоекономічній сфері. Узагальнимо їх у математичному виразі:

$\Pi_{\Phi \mathrm{n}}=\left\{\bigcup_{\mathrm{i}=1}^{23} \Pi_{\phi \mathrm{n}}\right\}=\left\{\begin{array}{c}\text { ROT; RLT;OM; OMM; } \\ \text { DBFO;DB;BLOT;BROT;BTO; DCMF; } \\ \text { DBOM;DBFOM;DBFOMT; } \\ \text { BOOT; BTO;BOT; } \\ \text { BOMT;DBOOT;BBO,BLT } \\ \text { DBO;DBM;BROT }\end{array}\right\}$

За масштабами та тривалістю проєкту ДПП у зовнішньоекономічній сфері $\left(\mathrm{MT}_{\Pi}\right)$, складові моделі ДПП можуть мати такі властивості: короткострокові проєкти ДПП (до 3 років) $\left(\Pi_{\kappa}\right)$, середньострокові проєкти ДПП (від 3 до 5 років) $\left(\Pi_{c}\right)$, довгострокові проєкти ДПП (понад 5 років) $\left(\Pi_{д}\right)$.Сформуємо множину станів для цього елементи моделі ДПП у зовнішньоекономічній сфері:

$$
\mathrm{MT}_{\Pi}=\left\{\bigcup_{i=1}^{3} \mathrm{MT}_{\Pi}\right\}=\left\{\Pi_{\mathrm{K}} ; \Pi_{\mathrm{c}} ; \Pi_{\mathrm{\mu}}\right\}
$$

Рівень ризиків державного і приватного сектору $\left(\mathrm{P}_{\text {рдпп }}\right)$ як елементи мо- 
делі ДПП може набути наступних станів: допустимий $\left(\mathrm{P}_{\text {д }}\right)$, критичний $\left(\mathrm{P}_{\text {кр}}\right)$, катастрофічний $\mathrm{P}_{\mathrm{KT}}$ :

$$
\mathrm{P}_{\mathrm{pдп \Pi}}=\left\{\bigcup_{\mathrm{i}=1}^{3} \mathrm{P}_{\mathrm{pд \Pi \Pi}}\right\}=\left\{\mathrm{P}_{д} ; \mathrm{P}_{\mathrm{\kappa p}} ; \mathrm{P}_{\mathrm{KT}}\right\}
$$

3 урахуванням станів, яких можуть набувати елементи моделі ДПП у зовнішньоекономічній сфері, їх декомпозицію можна здійснити так:

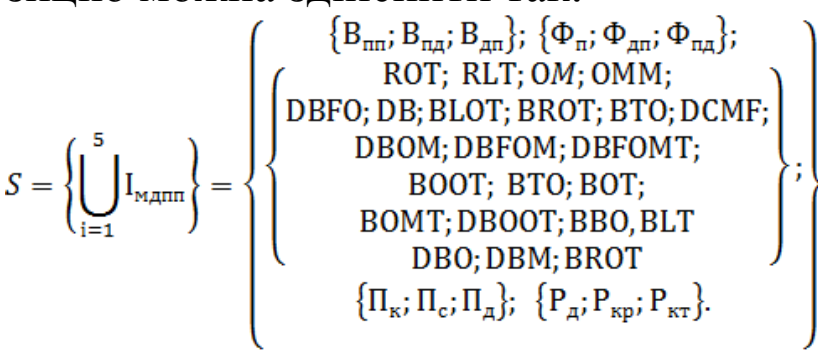

3 метою підвищення рівня реалізації проєктів ДПП у зовнішньоекономічній сфері та їх результативності, розглянемо можливість оптимізації моделей ДПП. Для цього до моделей ДПП у зовнішньоекономічній діяльності (включаючи їх структурну декомпозицію, що узагальнена у формулі 7) застосуємо структурний та об'єктноорієнтовний підходи до моделювання. Вони поширені у моделюванні бізнеспроцесів, що дозволяє підвищити ефективність реалізації всього комплексу бізнес-процесів підприємства, шляхом моделювання мережі процесів діяльності з усіма потоками і ресурсами підприємства, засобами формалізації [16]. До їх переваг віднесемо також можливість застосування методів графічного моделювання: UML, ARIS, IDEF (методологія опису бізнеспроцесів - стандарт США), BPMN. Зважаючи на те, що сутнісно проєкти ДПП у зовнішньоекономічній можуть буди представлені як сукупність дій, що ведуть до досягнення відповідного результату, можна здійснити їх фор- малізацію за допомогою ставлення взаємозв'язків виділених елементів.

О. В. Корзаченко для моделювання бізнес-процесів рекомендує використовувати: метод функціонального моделювання SADT (IDEF0); метод моделювання процесів IDEF3; моделювання потоків даних DFD; метод ARIS; метод EricssonPenker; метод моделювання, що використовується в технологіï RationalUnifiedProcess [17]. Проте автор акцентує увагу на таких методах, як SADT (IDEF0), IDEF3, DFD та методі побудови моделей за допомогою UML. Цю думку можна простежити у праці Я. О. Рожкової «Моделювання процесу управління фінансової діяльністю банку». Для моделювання Я. О. Рожкова рекомендує метод функціонального моделювання SADT (IDEF0), що належить докласичного методу процесного підходу до управління, основним принципом якого є структуризація діяльності організації відповідно до іï бізнеспроцесів. Під бізнес-процесами розуміється сукупність правил і процедур, що призначені для побудови функціональної моделі об'єкту будь-якої предметної області [18]. 3 метою збільшення результативності моделювання слід SADT поєднати із IDEF0, що дає точну специфікацію операцій та дій із реалізації бізнес-процесів та характеризують взаємозв'язки між ними.

Для моделювання ДПП у зовнішньоекономічній діяльності, виходячи iз рекомендованих в (7) елементів рекомендуємо такий порядок:

1.Формування мети і завдань моделювання ДПП у зовнішньоекономічній діяльності. Дане моделювання призначено для підвищення ефективності взаємодії у межах ДПП та у процесі реалізації рекомендованих моде- 
лей, дотримуючись критерію їх оптимальності.

2. Інформаційне забезпечення моделювання ДПП у зовнішньоекономічній діяльності, що передбачає збір усіх необхідних для процесу моделювання даних, їх перевірку на достовірність та опрацювання з метою використання у процесі моделювання.

3. Вибір методів та засобів, при значених для моделювання ДПП у зовнішньоекономічній діяльності. Нами обрано декомпозицію процесів ДПП у зовнішньоекономічній діяльності та поєднання SADT-моделей із стандартами IDEF0 як рекомендовано вище.

4. Безпосереднє моделювання, яке складається із формування контекст- ної діаграми «Модель ДПП у зовнішньоекономічній діяльності» та її подальшої декомпозиції. Контекстна діаграма вказує на основний процес взаємодії державного і приватного секторів та ключові елементи, які його визначають. Вона вказує на мету реалізації моделі ДПП у зовнішньоекономічній діяльності, може містити інформаційне забезпечення, нормативноправове підгрунтя реалізації тощо.

Декомпозиція контекстної діаграми «Модель ДПП у зовнішньоекономічній діяльності», що полягає в уточненні загальної моделі ДП та їх складових, кожна із яких визначає взаємодію державного та приватного секторів у межах проєкту (рис. 1).

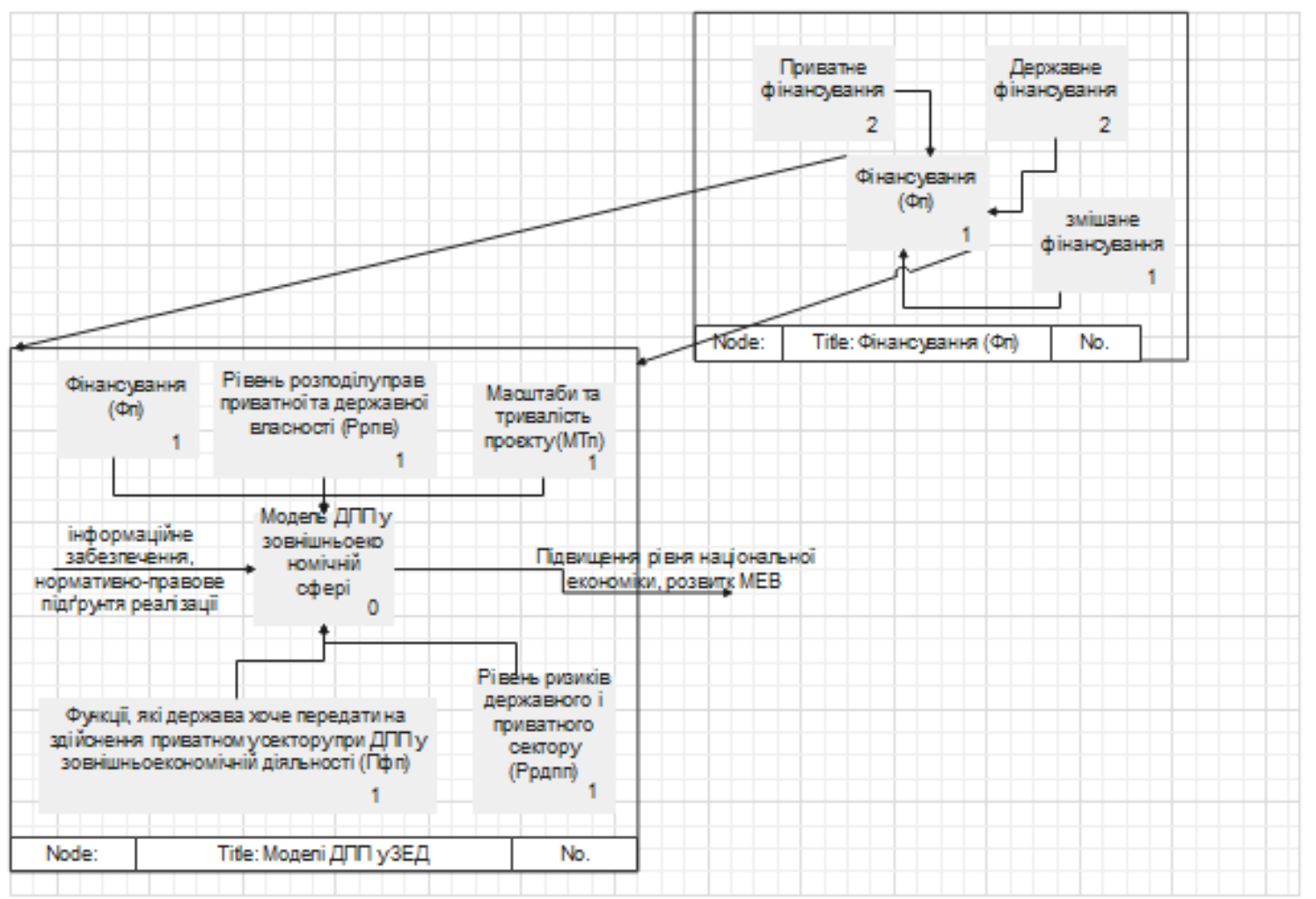

Рис. 1. Контекстна діаграма «Модель ДПП у зовнішньоекономічній діяльності» в стандарті IDEF0 та ії декомпозиція

Усі складові пов'язані між собою у процесі реалізації проєктів ДПП. Для прикладу, декомпозиція процесу «Фінансування $\left(\Phi_{\Pi}\right) »$ моделі ДПП перед- бачає визначення джерел фінансування проєкту ДПП у зовнішньоекономічній сфері, що впливатиме на його реалізацію. 
5. Використання результатів моделювання, вибір (уточнення, коригування) моделі ДПП у зовнішньоекономічній сфері.

Завдяки реалізації етапів структурно-функціонального моделювання ДПП у зовнішньоекономічній діяльності за допомогою SADT можна забезпечити вибір оптимальної моделі ДПП, яка враховує найбільш істотні елементи iii реалізації чи впливає на результативність проєктів ДПП.

Висновки. 3 метою розвитку ДПП у зовнішньоекономічній діяльності та підвищення результативності проєктів ДПП у статті досліджено моделі ДПП та визначено форми та механізми ДПП у зовнішньоекономічній сфері (табл. 1). У статті здійснено декомпо- зицію моделей ДПП, для чого застосовано структурний та об'єктноорієнтовний підходи до моделювання. У результаті сформовано відповідний порядок моделювання ДПП у зовнішньоекономічній діяльності: формування мети і завдань моделювання ДПП, інформаційне забезпечення моделювання, вибір методів та засобів, при значених для моделювання ДПП у зовнішньоекономічній діяльності, безпосереднє моделювання (поєднання SADT-моделей із стандартами IDEF0), використання результатів моделювання, вибір (уточнення, коригування) моделі ДПП у зовнішньоекономічній сферi.

\section{Список використаної літератури}

1. Підгаєць С. Європейський досвід застосування моделей державноприватного партнерства. Журнал європейської економіки, 2011. Том 10. № 3. С. 291-305. URL: http://jee.tneu.edu.ua/ua/archive/2011/vol-10-no-3-september-2011ua/.

2. Dewatripont M. \& Legros P. Public-private partnerships: contrac design and risk transfer. European Investment Bank (EIB) Papers, 2005. Volume 10. №. 1.

3. Мащенко М. А. Аналітичний огляд моделей державно-приватного партнерства у розрізі забезпечення інвайронментальної безпеки. Агросвіт, 2018. № 24. C. 31-35. URL: http://www.agrosvit.info/pdf/24_2018/6.pdf.

4. Editedby R. ScottFosler, Renee A. Berger. Lexington, Mass. Public-private partnership in American cities : seven case studies. LexingtonBooks, 1982. Р. 43-57.

5. Брайловський I. А. Передача активів - роздержавлення як одна із моделей державно-приватного партнерства. Вісник Національного університету «Юридична академія Украӥни імені Ярослава Мудрого», 2013. № 1 (12). С. 92-98. URL: http://econtlaw.nlu.edu.ua/wpcontent/uploads/2015/02/ekonom_12.pdf\#page=92.

6. Шилепницький П.І. Дослідження природи державно-приватного партнерства. Регіональна економіка, 2010. №3. С.187-194.

7. Брайловський I.А. Моделі державно-приватних партнерств. Держава та регіони, 2012. № 4 (40). C. 4 99-103. URL: http://pa.stateandregions.zp.ua/archive/4_2012/17.pdf

8. Хусаінов Р. Моделі державно-приватного партнерства: закордонний досвід та перспективи для України». Науковий вісник Одеського національного еконо- 
мічного університету, 2015. № 4 (224). C. 177-192. URL: http://nvisnik.oneu.edu.ua/collections/2015/224/.

9. Длугопольський О. В., Жуковська А. Ю. Державно-приватні партнерства: зарубіжний досвід і уроки для України. Актуальні проблеми економіки, 2012. № 3. C. 43-49. URL: http://nbuv.gov.ua/UJRN/ape_2012_3_7.

10. Шарингер Л. Новая модель инвестиционного партнерства государства и частного сектора. Мир перемен, 2004. №2. С. 13.

11. Кузьмина С. Н., Бабкин И. А. Принципы и моделигосударственночастного партнерства в промышленности и научно-инновационнойсфере. Becтник Забайкальского государственного университета, 2015. № 12 (127). С. 110-120.

12. Круглов В. В. Моделі державно-приватного партнерства. Держава та регіони, 2018. №2 (62). С. 56-61.

13. Вінник О.М. Форми та моделі державно-приватного партнерства. Університетські наукові записки, 2011. № 1 (37). С. 159-169.

14. Брайловський I. А. Державно-приватне партнерство: методологія, теорія, механізми розвитку : автореф. дис. ... д-ра. екон. наук : 08.00.01. Харків, 2015. $43 \mathrm{c}$.

15. Жук В. П. Організація державно-приватного партнерства в зарубіжних країнах. Інвестииії: практика $і$ досвід, 2012. № 11. C. 111-113 URL: http://www.investplan.com.ua/?op=1\&z=2038\&i=26.

16. Гадецька 3. М., Холопова М. О. Моделювання бізнес-процесів діяльності підприємства. Ефективна економіка, 2016. № 5. URL: http://nbuv.gov.ua/UJRN/efek_2016_5_12.

17. Корзаченко О. В. Моделювання бізнес-процесів підприємств: методології, підходи та методи. Науковий вісник Херсонського державного університету. Сер. : Економічні науки, 2015. Вип. 11(1). С. 171-175. URL: http://nbuv.gov.ua/UJRN/Nvkhdu_en_2015_11(1)_42.

18. Рожкова Я. О. Моделювання процесу управління фінансовою діяльністю банку. Актуальні питання економічних наук : матеріали IV Міжнародної науково-практичної конференції, $2017 . \quad$ C.135-139. URL: http://molodyvcheny.in.ua/files/conf/eko/24june2017/24june2017.pdf\#page=135. 